\title{
Pilot-Scale Electrochemical Treatment of Textile Effluent and its Toxicological Assessment for Tilapia (Oreochromis niloticus L.) Culture
}

\author{
Muhammad Anwar-ul-Haq ${ }^{1}$, Amer Jamal Hashmat ${ }^{1}$, Ejazul Islam ${ }^{1}$, Muhammad Afzal ${ }^{1}$ \\ Abid Mahmood ${ }^{2}$, Muhammad Ibrahim ${ }^{2, *}$, Muhammad Nawaz ${ }^{3, *}$, Shahid Nadeem ${ }^{4}$ and \\ Qaiser Mahmood Khan' \\ ${ }^{1}$ Environmental Biotechnology Division, National Institute for Biotechnology and \\ Genetic Engineering, Jhang Road, Faisalabad \\ ${ }^{2}$ Department of Environmental Sciences and Engineering, Government College \\ University, Faisalabad \\ ${ }^{3}$ Department of Botany, Government College University, Faisalabad \\ ${ }^{4}$ Animal Sciences Division, Nuclear Institute for Agriculture and Biology, Faisalabad
}
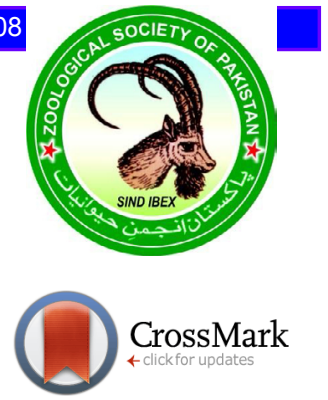

\begin{abstract}
A B S T R A C T
The present study deals with the treatment of textile effluent using electrochemical techniques on pilot scale $(70 \mathrm{~L})$. One of the major problems encountered in the textile industry is the production of large volumes of highly colored wastewater. The scope of this new electrochemical treatment is a significant advance to the existing technologies. There were four different treatments employed as; T1: wastewater, T2: wastewater with $0.1 \%$ electrolyte, T3: diluted wastewater (50\% tap water), and T4: diluted wastewater $(50 \%$ tap water) with $0.1 \%$ electrolyte. The color and COD in the effluent were reduced to $47 \%$ and $46 \%$ in $\mathrm{T} 1$, $70 \%$ and $52 \%$ in $\mathrm{T} 2,75 \%$ and $57 \%$ in $\mathrm{T} 3,80 \%$ and $59 \%$ in $\mathrm{T} 4$, respectively by using iron plate electrodes in four hours. The toxicological studies proved that electrochemical treatment could effectively detoxify the effluent. The mortality rate of Tilapia (Oreochromis niloticus L.) was $70 \%$ decreased in treated textile effluent as compared to untreated textile effluent. Overall, electrochemical treatment process has been proved to be efficient in reducing COD, color and toxicity and thus treated water can be reused.
\end{abstract}

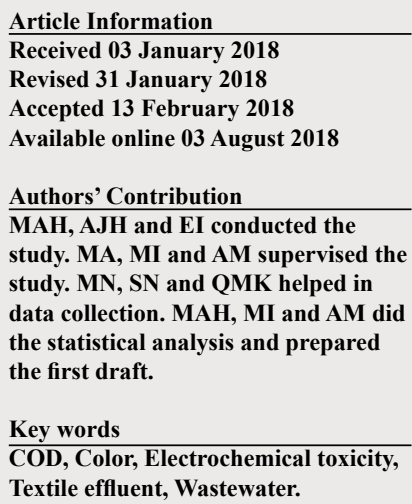

\section{INTRODUCTION}

$\mathrm{T}$ he water is one of the most important needs to sustain life. However, its sources are being reduced and contaminated with ever increasing population of the world. Total dissolved and suspended solids, colour and chemical oxygen demand (COD) are the important features for quality measurements of waste water produced in textile industry (Sheikh, 2009). The COD indicates the total oxygen demand of waste water including oxidizable components. This feature is considered as on the most important quality assurance parameter of industrial effluents prior to discharge in open sources. The tangible threats of solids and color in industrial effluent are due to dye toxicity. The coloring agents interfere strongly with the transmission of light through the water, thus hampering photosynthesis process in aquatic plants (Al-Kdasi et al., 2004). Many treatment methods based on advanced

\footnotetext{
Corresponding authors: ebrahem.m@gmail.com; m.nawaz9@gmal.com 0030-9923/2018/0005-1703 \$ 9.00/0

Copyright 2018 Zoological Society of Pakistan
}

technology are being exploited for this purpose these days. These treatment processes neither improve primary and secondary treatment nor replace the biological methods. They are aimed at improving the quality of waste water to the degree at which it can be reused or discharged safely into the environment (Gulfraz et al., 2002; Mohan et al., 2007; Lopes et al., 2004). Numerous classical and advance treatment methods are being modified (European Commission, 2011). Many methods have been developed to remove chemical substances found in industrial effluents discharged directly in to environment (Mehmet et al., 2003; Raghu and Ahmed-Basha, 2007).

Electrochemical technology has been granted as most effective and economical method for the removal of major chemical components found in textile effluent. The introduction of this new electrochemical treatment is a significant addition to the existing technologies being used fot this purpose. In this process the aqueous waste is simply passed between two iron plates under DC current application. According to Faraday's Law, $\mathrm{Fe}^{+2}$ and $\mathrm{OH}^{-}$ are generated by these electrodes. The insoluble $\mathrm{Fe}(\mathrm{OH})_{3}$ formed is precipitated removed from the effluent waste. (Carneiro et al., 2004; Hepel and Luo, 2001). 
The electrochemical system performs multiple activities including reduction of COD from effluent waste, elimination of color constituents of dyes and pigments and coagulation of the total suspended solids present in the effluent waste of industries (Yang and McGarrahan, 2005). The electrochemical method of pollution removal presents many important advantages and is applicable on a large range of pollutants. Industrial wastewater contains a cosmic range of pollutants: insoluble, colloidal, and particulate forms, both organic and inorganic nature. Electrochemical treatment reactions are labeled as redox (reduction/ oxidation) procedures. Electron transmission occurs at borders between a metallic conductor (an electrode) and an ionic conductor (an electrolyte) electrochemical depollution is a very efficient and economic method, suitable for the wastewater containing toxic or nonbiodegradable organic and inorganic pollutants.

Electrochemical technologies have the advantage that the electrode processes involve only the removal (oxidation) or addition (reduction) of electrons. No addition of chemicals is in principle required, thus making electrolysis a very 'green' technology (Kaul et al., 2004). The electrochemical treatment technologies have attained a well-recognized status these days and are not only better in terms of cost but also considered more efficient and compact as compared to other parallel procedures. Electrochemical methods for waste control have several inherent advantages (Rajashekharam et al., 1998). An effective electrochemical system will use a minimal amount of energy to transform refractory compounds and their by-products into biodegradable and nontoxic forms (Merias et al., 2005). This approach in lower energy demands thus can offer considerable money saving for industry and local governments. There is need of hour to reduce pollution and conserve our reservoirs to feed next generations. The industrial effluent after treatments may be used in fish culture ponds. It may serve as one of the important pillars to raise the aqua culture industry in the country.

The most important objective of the current study was to treat textile effluents containing dyes. The reduction of color, COD and toxicity were the primary objectives of the study. The secondary objectives of the study included electrochemical reactor performance by measuring electrodes efficiency, color reduction, COD removal efficiencies, energy consumptions and toxicity reduction of treated effluent by fish toxicity assay.

\section{MATERIALS AND METHODS}

\section{Sampling}

The wastewater samples were collected from textile industries located at Faisalabad, Pakistan. Representative samples were collected randomly after every hour for a total period of $6 \mathrm{~h}$. To avoid changes in COD, colour and other properties of samples, they were placed in ice boxes and transported to the laboratory and were kept in cold room at $4^{\circ} \mathrm{C}$. After that, the samples were analyzed for various physico-chemical parameters such as COD, color and toxicity according to the standard methods (Table I).

\section{Experimental setup}

The experiments were conducted in an electrolytic cell comprising cathode, anode and the power supply unit. The electrodes plates were of rectangular shape. The electric current intensity was adjusted to the desired value and the voltage was automatically regulated to match the current value. All runs were conducted at room temperature. Four treatments were employed as; T1: wastewater, T2: wastewater plus $0.1 \%$ electrolyte, T3: diluted wastewater (50\% distilled water) and T4: diluted wastewater (50\% distilled water) plus $0.1 \%$ electrolyte. All runs were made at effluent's ambient $\mathrm{pH}-7$. The $\mathrm{pH}$ of the experiment was continuously monitored throughout the experiment.

\section{Characteristics of the electrochemical treatment cell}

Iron electrodes with rectangular plate shape and size $24 \mathrm{~cm} \times 88 \mathrm{~cm}$, thickness $2.5 \mathrm{~mm}$ with parallel plate arrangement were used. The reactor was made up of perspex organic glass, having dimensions $29 \mathrm{~cm} \times 29 \mathrm{~cm} \times$ $90 \mathrm{~cm}$, volume $70 \mathrm{dm}^{3}$, electrode gap $5 \mathrm{~cm}$, power supply direct current (DC), Voltage range $12 \mathrm{~V}$, and current range 900-1000 mA.

\section{Determination of COD and color}

COD was determined according to standard method (Clesceri et al., 1998). For determination of color, $\lambda \max$ of each sample was determined by UV-visible spectrophotometer. Changes in color from the absorption of each effluent sample before and after treatment were recorded.

\section{Acute toxicity testing}

Toxicity testing of wastewater was conducted by using a freshwater fish Tilapia. Textile wastewater was analyzed for toxicity testing before and after electrochemical treatment. During acclimation period (one week), the young fish were fed regularly with commercially available fish food and were transferred in glass aquaria. Aeration was supplied through air compressor pump to maintain the dissolved oxygen in the experimental aquaria. The first aquarium was kept as control. After different treatments of textile wastewater, it was given in remaining experimental aquaria. About ten fish were selected for each of the 
experimental aquaria. The results showed in this paper represent the T4 treatment. Dead fish, if any were removed from the aquaria. The mortality data of fish was recorded daily for $48 \mathrm{~h}$ as reported by Ismail (Ismail et al., 2009).

\section{RESULTS AND DISCUSSION}

\section{Wastewater characteristics}

Analyses of wastewater were carried out before any kind of treatment and the results are mentioned in Table I. The effluent was found to be highly alkaline, with high values of COD, color. Moreover, the untreated water was toxic in nature. The parameters estimated had high range of pollutants as compared to NEQS values.

Table I.- Characteristics of composite textile industry wastewater with NEQS values.

\begin{tabular}{lcc}
\hline Parameters & Values & NEQS \\
\hline $\mathrm{pH}$ & $8 \pm 2.5$ & $6-10$ \\
$\mathrm{COD}(\mathrm{mg} / \mathrm{L})$ & $1768 \pm 145$ & 150 \\
$\mathrm{BOD}(\mathrm{mg} / \mathrm{L})$ & $210 \pm 17$ & 80 \\
$\mathrm{TSS}(\mathrm{mg} / \mathrm{L})$ & $500 \pm 58$ & 150 \\
$\mathrm{TDS}(\mathrm{mg} / \mathrm{L})$ & $5900 \pm 58$ & 3500 \\
$\mathrm{TS}(\mathrm{mg} / \mathrm{L})$ & $6400 \pm 115$ & 3650 \\
Color $\left(\mathrm{m}^{-1}\right)$ & $1.6 \pm 0.12$ & $\mathrm{NG}$ \\
\hline
\end{tabular}

Each value is a mean of three replicates and \pm indicates the standard error among them. NEQS, National Environment Quality Standards of Pakistan; NG, Not given in NEQS list.

\section{Effect of dilution on electrochemical treatment of textile effluent}

It was observed that by using iron plate electrodes in a 70 liter cell for eight hours, the color was reduced to $47 \%$, (Fig. 1A) and COD was reduced to $46 \%$ (Fig. 1B) in T1 having real effluent without any dilution (T1). Under the same conditions when effluent was diluted with tap water in the ratio of $50 \%$ tap water, (T3), color was reduced to $80 \%$ and COD was reduced to $59 \%$ in a 70 liter electrochemical cell (Fig. 1A, B, respectively).

\section{COD reduction}

The level of COD is a critically important factor in evaluating the extent of organic pollution in textile wastewater. In electrochemical treatment of wastewater from textile industry, COD values were lowered by $46 \%$ in $\mathrm{T} 1,52 \%$ in $\mathrm{T} 2,57 \%$ in $\mathrm{T} 3$, and $59 \%$ in $\mathrm{T} 4$. The COD reductions presumably resulted from adsorption of the organic constituents onto the precipitating metal hydroxide matrix. It was also observed that the effect of additional electrolytes also enhanced the reduction rate of COD (Chen, 2004). The effluents from textiles were complex and accordingly, must be assessed by a tailor- made combination electrochemical series of cells. It has been accepted in the current years that toxic components of textile effluents represent a great environmental hazard over long distances and time periods (Rosa et al., 2001; Wali, 2015).
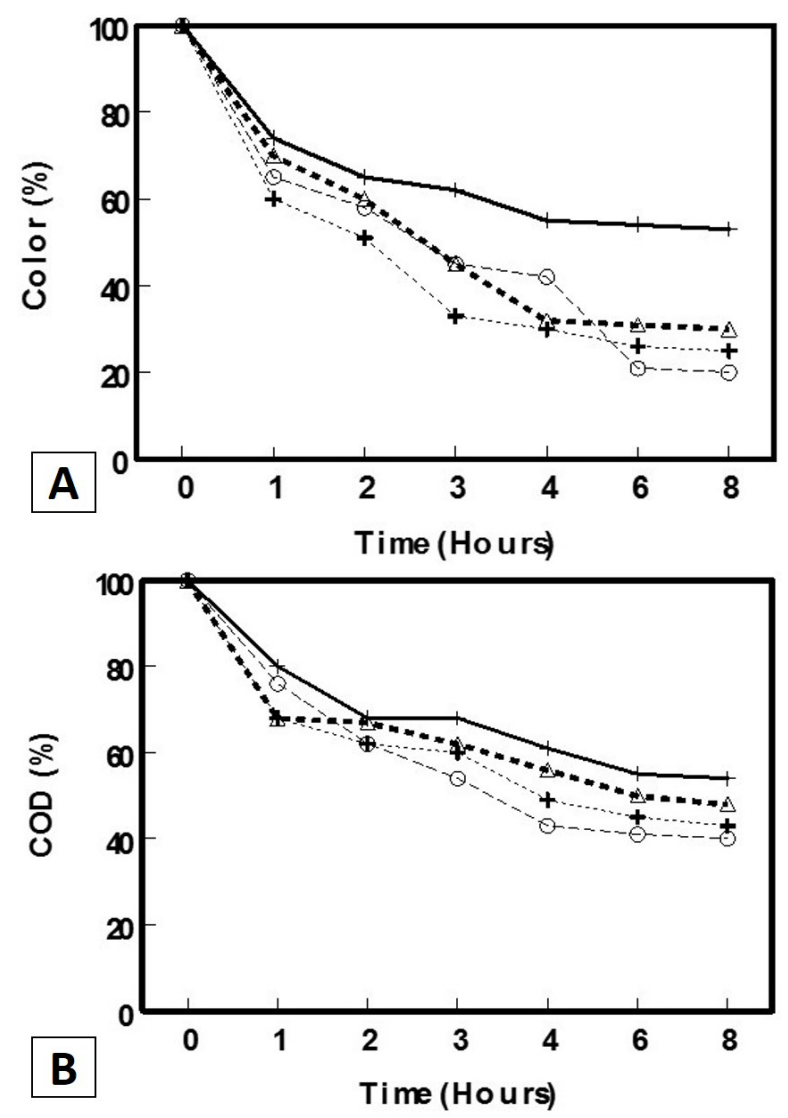

Fig. 1. The color (A) and COD reduction (B) of textile wastewater under different treatments. $\mathrm{T} 1$, + wastewater; $\mathrm{T} 2, \Delta$ wastewater plus $0.1 \%$ electrolyte; $\mathrm{T} 3,+$ wastewater (50\% diluted); T4, $\bigcirc$ wastewater (50\% diluted) plus $0.1 \%$ electrolytes.

\section{Color reduction}

The use of electrochemical methods for color exclusion involved tests on pure dye samples along with actual textile effluent. The incidence of color in textile effluent could be seen as pollution and many dyes biodegrade very slowly and are potentially lethal to plant and animal life. Rules for color valuation in textile effluent are indefinable at preset primarily, due to non-availability of economical technology to treat the flow rates involved. Figure 1A represents obvious results of color removal from wastewater under different treatments. Reduction in color was estimated up to $47 \%$ in $\mathrm{T} 1,70 \%$ in $\mathrm{T} 2,75 \%$ in T3, $80 \%$ in T4 by using iron plate electrodes. Diluted 
effluent affected the color removal efficiency and it was also observed that the affect of additional electrolytes also enhanced the reduction rate of color. These results indicate that electrochemical treatment for color removal is very broad in scope and efficient in many cases.

The results obtained from the study also indicated that concentration of the effluent affected the efficiency of treatment plant. The broken-down metabolites are not hazardous generally making it safe for treated effluents to be released back into water ways. It shows efficient and economical removal of dyes and a high efficiency for color removal and degradation of recalcitrant compounds (Ogutveren and Koparal, 1994; Pelegrini et al., 1999). A decreased amount of dye is removed under high flow rates and electricity cost is comparable to the cost of chemicals (Butler et al., 2011). Additions of electrolyte under T4 treatment accelerated the reaction rates due to ion formation which helps in current flow from electrodes. The supporting electrolyte enhanced the treatment performance as were shown from the results. Entire elimination of the color present in textile effluent is possible using $\mathrm{NaCl}$ in electrolyte under high current densities. Variation in the reaction conditions indicates that a careful consideration is required when constructing an electrochemical treatment system (Malpass et al., 2007).

The removal of color is important; it is not essentially a signal that the effluent is fit to be released in to the drain open sources (Malpass et al., 2007). In this context our continuing studies concern the variation of toxicity before and after the treatment. Studied of electrochemical treatment process for textile effluents was conducted (Sakalis et al., 2005) and found to be effective than other available techniques. Color was found to be reduced up to $80 \%$ in T4 treatment, a similar trend was also observed by Vlyssides et al. (2000). The application of electrolyte and different dilutions of effluents affect the color removal rate of the treatment methods.

\section{Fish toxicity testing of untreated and electrochemically treated textile effluent}

Textile effluent is present in ground water and surface water, so it is toxic to aquatic organism (Abo-Elela and Wahaab, 1988). The present study was designed to find the toxicity of textile effluent in fish and fish mortality data was recorded at different time intervals as shown in Table II. The tilapia (Oreochromis niloticus L.) fish was used for toxicity testing studies. Fish mortality was calculated by keeping fish in controlled condition of real effluent without treatment and electrochemical treated wastewater was compared in this study. Textile effluent affected the fish of the treated aquarium. A property of Tilapia fish is that these fish remain in the grouped form, but when textile effluent was added, the fish remained scattered i.e. the grouping was distributed as compared with the fish in control.

Mortality data was recorded after 1, 2, 3, 4, 8, 24 and $48 \mathrm{~h}$ by using real textile wastewater and electrochemical treated wastewater. The respiration rate per min in treated fish was less, as compared with control. The distance traveled by the fish in the un-treated aquarium was less as compared with fish in treated aquarium. Fish mortality was observed and was found that at electrochemical treated wastewater for eight hours shows low mortality at $24 \mathrm{~h}$ (Table II). The results showed that after treatment, the effluent became less toxic as compare to untreated. It has been reported that some effluents, genotoxic and immune end points may be more sensitive than estrogenic (endocrine-mediated) end points as indicators of exposure in fish (Liney et al., 2006).

Table II.- Mortality data of fish toxicity testing using real textile effluent and electrochemically treated textile effluent.

\begin{tabular}{lcc}
\hline Time of exposure (h) & No of fish died & No. of fish alive \\
\hline Real textile effluent & 0 & 10 \\
0 & 06 & 04 \\
1 & 06 & 04 \\
2 & 07 & 03 \\
4 & 09 & 01 \\
8 & 10 & 0 \\
24 & 10 & 0 \\
48 & 0 & \\
Electrochemically treated textile effluent & 10 \\
0 & 0 & 10 \\
1 & 0 & 10 \\
2 & 01 & 09 \\
4 & 02 & 08 \\
8 & 02 & 08 \\
24 & 03 & 07 \\
48 & & \\
\hline
\end{tabular}

In case of untreated textile effluent, there was more death of fish as compared to treated effluents. Several studies indicated that wastewater affect the fish physiology, pathology, biochemical measures and reproduction (Owens, 1991; Yogendra et al., 2005). In general, the treated textile effluent was either least toxic or non-toxic (Merias et al., 2004, 2005). Results of the present study showed that after treatment, the effluent became less toxic as compared to untreated effluent. However, after treatment, effluent could not cause the death of fish, showing that its toxicity was reduced. The efficiencies in COD, BOD and toxicity removal by electrochemical treatment of simulated textile effluents are similar as findings in literature (Korbahti and 
Abdurrahman, 2008; Wells et al., 1994).

Energy consumption for electrochemical treatment of textile effluent

Energy consume during an electrochemical reaction was calculated as $0.096 \mathrm{KW} / \mathrm{h}$ for the iron electrode materials. During electrochemical treatment reaction, the current density passed was $1.0 \mathrm{~A}$ and $12 \mathrm{~V}$ for $8 \mathrm{~h}$. Energy consumption was directly proportional to time of reaction. It was found that if we finish electrochemical reaction in four hours, the energy consumption value reduced to half.

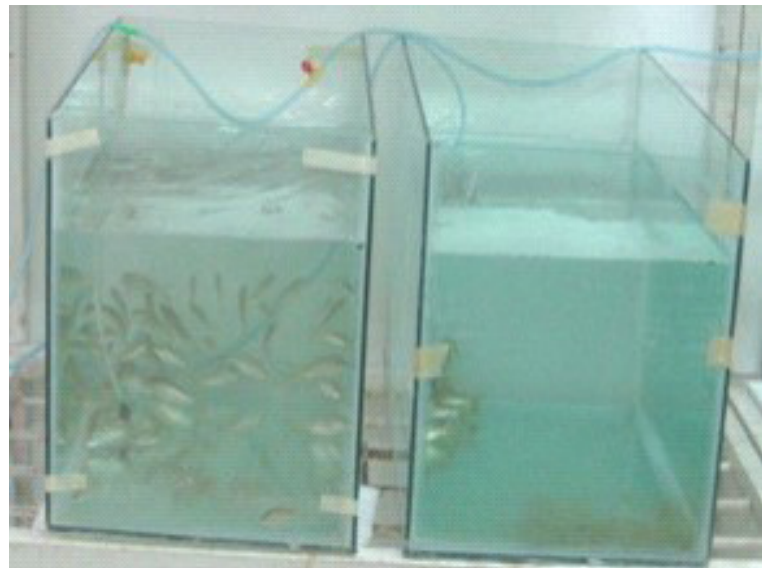

Fig. 2. Experimental set up of toxicological assessment for Tilapia (Oreochromis niloticus L.) culture.

\section{CONCLUSIONS}

In this study textile effluent was treated using electrochemical technique. The effect of primary effluent concentration, dilution, and supporting electrolyte concentration on COD and color reduction using iron electrodes has been studied critically. It has been concluded that the percentage of COD and color reduction is meaningfully influenced by the initial effluent concentration, supporting electrolyte concentrations and dilution. The performance of electrochemical treatment of textile waste water is increased significantly in the presence of an electrolyte. The process is recommended to be a cheaper and economical solution for industrial waste water treatment. The resultant effluent could be discharged into water bodies without any risk and may be used in water rearing ponds of fisheries.

\section{Statement of conflict of interest}

Authors have declared no conflict of interest.

\section{REFERENCES}

Abo-Elela, S.I. and Wahaab, R.S.A., 1988. Fish toxicity bioassays of textile wastewaters using Nile Bulti. Environ. Technol. Lett., 9: 1147-1152. https://doi. org/10.1080/09593338809384676

Al-Kdasi, A., Idris, A., Saed, K. and Guan, C.T., 2004. Treatment of textile wastewater by advanced oxidation processes - A review. Glob. Nest Int. J., 6: $222-230$.

Butler, E., Hung, Y.T., Yeh, R.Y.L. and Suleiman Al Ahmad, M., 2011. Electrocoagulation in wastewater treatment. Water, 3: 495-525. https:// doi.org/10.3390/w3020495

Carneiro, P.A., Osugi, M.E., Sene, J.J., Anderson, M.A. and Zanoni, M.V.B., 2004. Evaluation of color removal and degradation of a reactive textile azo dye on nanoporous $\mathrm{TiO} 2$ thin-film electrodes. Electrochim. Acta, 49: 3807-3820. https://doi. org/10.1016/j.electacta.2003.12.057

Chen, G., 2004. Electrochemical technologies in wastewater treatment. Separ. Purific. Technol., 38: 11-41. https://doi.org/10.1016/j. seppur.2003.10.006

Clesceri, L.S., Greenberg, A.E. and Eaton, A.D., 1998. Standard methods for the examination of water and wastewater, $20^{\text {th }}$ Edition. American Public Health Association, Washington DC.

European Commission, 2011. Common implementation strategy for the Water Framework Directive (2000/60/EC), Technical guidance for deriving environmental quality standards. Guidance Document 27. Tech. Rep. 2011-055. Brussels, Belgium.

Funke, B., Kolb, M., Baur, A., Schulz, W., 1985. Decolorization of textile waste water by means of iron(II)- salt and calciumhydroxide. Vom Wasser, 65: 139-144.

Gulfraz, M., Mussaddeq, Y., Khannum, R. and Ahmad, T., 2002. Quality assessment of effluents from various industries in the vicinity of Rawalpindi and Islamabad. On Line J. biol. Sci., 2: 697-698. https:// doi.org/10.3923/jbs.2002.697.698

Hepel, M. and Luo, J., 2001. Photoelectrochemical mineralization of textile diazo dye pollutants using nanocrystalline WO3 electrodes. Electrochim. Acta, 47: 729-740. https://doi.org/10.1016/S00134686(01)00753-8

Ismail, M., Ali, R., Ali, T., Waheed, U. and Khan, Q., 2009. Evaluation of the acute toxicity of profenofos and its effects on the behavioral pattern of fingerling common carp (Cyprinus carpio L., 1758). Bull. environ. Contam. Toxicol., 82: 569-573. https://doi. org/10.1007/s00128-009-9670-3

Kaul, S.N., Lidia, S. and Arvind, K., 2004. Wastewater 
treatment technologies and environment. Daya Publishing House, New Delhi, India.

Korbahti, B.K. and Abdurrahman, T., 2008. Electrochemical treatment of simulated textile wastewater with industrial components and Levafix Blue CA reactive dye: Optimization through response surface methodology. J. Hazard. Mat., 151: 422-431. https://doi.org/10.1016/j. jhazmat.2007.06.010

Liney, K.E., Hagger, J.A., Tyler, C.R., Depledge, M.H., Galloway, T.S. and Jobling, S., 2006. Health effects in fish of long-term exposure to effluents from wastewater treatment works. Environ. Hlth. Perspect., 114(Suppl 1): 81-89. https://doi. org/10.1289/ehp.8058

Lopes, A., Martins, S., Morao, A., Magrinho, M. and Goncalves, I., 2004. Degradation of a Textile Dye C. I. Direct Red 80 by electrochemical processes. Portug. Electrochim. Acta, 22: 279-294. https://doi. org/10.4152/pea.200403279

Malpass, G.R.P., Miwa, D.W., Mortari, D.A., Machado, S.A.S. and Motheo, A.J., 2007. Decolorisation of real textile waste using electrochemical techniques: Effect of the chloride concentration. Water Res., 41: 2969-2977. https://doi.org/10.1016/j. watres.2007.02.054

Mehmet, K., Orhan, T.C. and Mahmut, B., 2003. Treatment of textile wastewaters by electrocoagulation using iron and aluminum electrodes. J. Hazard. Mat., 100: 163-178. https:// doi.org/10.1016/S0304-3894(03)00102-X

Merias, S., Kaptan, D. and Olmez, T., 2004. Color and COD removal from wastewater containing Reactive Black 5 using Fenton-oxidation process. Chemosphere, 54: 435-441. https://doi. org/10.1016/j.chemosphere.2003.08.010

Merias, S., Selauk, H. and Belgiorno, V., 2005. Acute toxicity removal in textile finishing wastewater by Fenton's oxidation, ozone and coagulation flocculation processes. Water Res., 39: 1147-1153. https://doi.org/10.1016/j.watres.2004.12.021

Mohan, N., Balasubramanian, N. and Basha, C.A., 2007. Electrochemical oxidation of textile wastewater and its reuse. J. Hazard. Mat., 147: 644-651. https://doi. org/10.1016/j.jhazmat.2007.01.063

Ogutveren, U.B. and Koparal, S., 1994. Color removal from textile effluents by electrochemical destruction. J. environ. Sci. Hlth. Part A: Environ. Sci. Engin. Toxicol., 29: 1-16.

Owens, J.W., 1991. The hazard assessment of pulp and paper effluents in the aquatic environment: A review. Environ. Toxicol. Chem., 10: 1511-1540. https://
doi.org/10.1897/1552-8618(1991)10[1511:THAO $\mathrm{PA}] 2.0 . \mathrm{CO} ; 2$

Pelegrini, R., Peralta-Zamora, P., De Andrade, A.R., Reyes, J. and Duran, N., 1999. Electrochemically assisted photocatalytic degradation of reactive dyes. Appl. Catal. B: Environ., 22: 83-90. https:// doi.org/10.1016/S0926-3373(99)00037-5

Raghu, S. and Ahmed-Basha, C., 2007. Chemical or electrochemical techniques, followed by ion exchange, for recycle of textile dye wastewater. J. Hazard. Mat., 149: 324-330. https://doi. org/10.1016/j.jhazmat.2007.03.087

Rajashekharam, M.V., Jaganathan, R. and Chaudhari, R.V., 1998. A trickle-bed reactor model for hydrogenation of 2,4 dinitrotoluene: experimental verification. Chem. Engin. Sci., 53, 787-805. https:// doi.org/10.1016/S0009-2509(97)00366-7

Rosa, E.V.C., Simionatto, E.L., de Souza Sierra, M.M., Bertoli, S.L. and Radetski, C.M., 2001. Toxicity-based criteria for the evaluation of textile wastewater treatment efficiency. Environ. Toxicol. Chem., 20: 839-845. https://doi.org/10.1002/ etc. 5620200420

Sakalis, A., Mpoulmpasakos, K., Nickel, U., Fytianos, K. and Voulgaropoulos, A., 2005. Evaluation of a novel electrochemical pilot plant process for azodyes removal from textile wastewater. Chem. Engin. J., 111: 63-70. https://doi.org/10.1016/j. cej.2005.05.008

Sheikh, M.A., 2009. Environmental issues related with textile sector. Pakistan Textile J., 10: 36-40.

Vlyssides, A.G., Papaioannou, D., Loizidoy, M., Karlis, P.K. and Zorpas, A.A., 2000. Testing an electrochemical method for treatment of textile dye wastewater. Waste Manage., 20: 569-574. https:// doi.org/10.1016/S0956-053X(00)00028-3

Wali, F.K.M., 2015. Color removal and COD reduction of dyeing bath wastewater by Fenton reaction. Int. J. Waste Resour., 5: 171. https://doi. org/10.4172/2252-5211.1000171

Wells, M.J.M., Rossano, A.J. and Roberts, E.C., 1994. Textile wastewater effluent toxicity identification evaluation. Arch. environ. Contam. Toxicol., 27: 555-560. https://doi.org/10.1007/BF00214849

Yang, C.L. and McGarrahan, J., 2005. Electrochemical coagulation for textile effluent decolorization. $J$. Hazard. Mat., 127: 40-47. https://doi.org/10.1016/j. jhazmat.2005.05.050

Yogendra, V., Ruparelia, S.G., Hargan, M.C. and Kulkarni, P.K., 2005. Acute toxicity of the waste water of textile mills to water flea. J. Exobiol., 17: 67-73. 